\title{
An Experimental and Kinetic Study of the Sorption of Carbon Dioxide onto Amine-Treated Oil Fly Ash
}

\author{
Mohammed A. Saad, ${ }^{1}$ Mohammed J. Al-Marri, ${ }^{2}$ Ali L. Yaumi, ${ }^{3}$ \\ Ibnelwaleed A. Hussein, ${ }^{2,3}$ and Reyad Shawabkeh ${ }^{3}$ \\ ${ }^{1}$ Department of Chemical Engineering, Qatar University, P.O. Box 2713, Doha, Qatar \\ ${ }^{2}$ Gas Processing Center, Qatar University, P.O. Box 2713, Doha, Qatar \\ ${ }^{3}$ Department of Chemical Engineering, King Fahd University of Petroleum \& Minerals, Dhahran 31261, Saudi Arabia \\ Correspondence should be addressed to Reyad Shawabkeh; rshawabk@kfupm.edu.sa
}

Received 10 October 2015; Revised 30 December 2015; Accepted 4 January 2016

Academic Editor: Tomokazu Yoshimura

Copyright (C) 2016 Mohammed A. Saad et al. This is an open access article distributed under the Creative Commons Attribution License, which permits unrestricted use, distribution, and reproduction in any medium, provided the original work is properly cited.

\begin{abstract}
A new $\mathrm{CO}_{2}$ adsorbent is produced from waste oil fly ash (OFA). Ammonium hydroxide solution is used to convert OFA to activated carbon. Then, the product is used for the adsorption of $\mathrm{CO}_{2}$ from a nitrogen/carbon dioxide $\left(\mathrm{N}_{2} / \mathrm{CO}_{2}\right)$ gas mixture. The OFA samples are characterized by several techniques. Chemical treatment of OFA considerably changed its surface morphology. In particular, its surface area, as determined by BET measurements, increased from 59 to $318 \mathrm{~m}^{2} / \mathrm{g}$. The amine-functionalized ash had a monolayer adsorption capacity of $74.51 \mathrm{mg} / \mathrm{g}$ and was obtained at relative pressure, $0.05<p / p_{s}<0.35$. A kinetics study showed that the $\mathrm{CO}_{2}$ adsorption capacity of OFA increased with increasing $\mathrm{CO}_{2}$ flow rates and concentrations and decreasing the relative humidity. Unlike physical adsorption, the chemisorption process resulted in increased adsorption capacity with increasing temperatures over the range $0-40^{\circ} \mathrm{C}$. We also found that the adsorption process was endothermic $(80-173 \mathrm{~kJ} / \mathrm{mol})$. The isotherm data for the adsorption process were fitted using different models. The saturation capacity determined from the Sips model, which corresponds to the sum of the saturation capacities of all of the adsorbed layers, was $540.3 \mathrm{mg} / \mathrm{g}$ of ash.
\end{abstract}

\section{Introduction}

The emission of $\mathrm{CO}_{2}$ from the combustion of fossil fuels and other sources has recently increased the $\mathrm{CO}_{2}$ concentration in the atmosphere to an alarming level of $400 \mathrm{ppm}$ [1]. Human activities result in the emission of approximately 29 billion tons of $\mathrm{CO}_{2}$ into the atmosphere per year, where it acts as a heat-trapping greenhouse gas. Among all greenhouse gases, $\mathrm{CO}_{2}$ is potentially the highest contributor to the climate change [2]. Stabilizing the $\mathrm{CO}_{2}$ content of the atmosphere can potentially be achieved by the capture and sequestration of $\mathrm{CO}_{2}$ from its primary emission sources. $\mathrm{CO}_{2}$ can be recovered using processes such as membrane separation, liquid solvent absorption using amines, and pressure/temperature swing adsorption or cryogenic techniques [3]. However, the amine-based processes that are currently used in chemical plants to separate $\mathrm{CO}_{2}$ require large amounts of water and are energy intensive [1]. Additionally, these processes are associated with the generation of byproducts, corrosion of processing equipment, and a high energy of regeneration $[4,5]$.

Solid adsorbents also have potential to be used in separating $\mathrm{CO}_{2}$ from gas stream, because they require relatively little energy and can be applied easily over a wide range of temperatures and pressures [5-9]. However, the effectiveness of this technique depends on the development of durable and easily regenerable adsorbents with high selectivity and adsorption capacities [10]. Such materials include activated carbons, carbo-aluminosilicates, zeolites, fly ash, and metal oxides [11]. Promising results are obtained using zeolites to separate $\mathrm{CO}_{2}$ from gas streams. At low temperatures (20$50^{\circ} \mathrm{C}$ ), these aluminosilicate-based materials are known to exhibit a high adsorption capacity because of their large internal pore volumes, structural features, molecular pore sizes, and wide range of chemical composition [12]. However, the adsorption capacities of these materials decrease rapidly as 
the temperature increases $[13,14]$. Moreover, the adsorption ability of aluminosilicates is affected by the presence of water due to hydrophilic nature of these materials [15]. Unlike zeolites, activated carbon does not require moisture removal and has a large surface area and an easily modifiable pore structure. However, the use of carbon-based materials as an adsorbent for $\mathrm{CO}_{2}$ separation is limited as a result of the high sensitivity of these materials to the temperatures that are associated with power plant flue gases [1].

Fly ash (FA) is a byproduct of the combustion of fuel oil in power plants that is normally collected using cyclones (mechanical devices) or electrostatic precipitators. It is estimated that worldwide generation of fly ash is 750 million tones where China is the largest producer with amount of 580 million tons in 2015 [16]. FA can be used in a range of applications, including water pollution control [17], agriculture [18], and metal recovery $[19,20]$. However, FA is a major waste material and requires proper disposal. Worldwide, approximately $25 \%$ of the fly ash that is produced annually is used. In the United States and China, large amounts of fly ash are produced, at utilization levels of $32 \%$ and $40 \%$, respectively $[21,22]$. Thus, fly ash is an abundant and economical adsorbent precursor that can be used to treat flue gases as well as recover metals from wastewater [23]. Several researchers have used fly ash for these purposes. For instance, Mercedes Maroto-Valer et al. [24] used amineenriched fly ash to separate $\mathrm{CO}_{2}$ from a gas stream. Panday et al. [25] demonstrated the suitability of using ash from a thermal power plant for the removal of copper from aqueous solutions. The copper adsorption capacity of the solid adsorbent (ash) was dependent on the concentration, temperature, and $\mathrm{pH}$ of the solution.

Recently, our group developed a new activated OFA using various oxidizing agents such as sulfuric and nitric acids and the resulting products were used for $\mathrm{CO}_{2}$ capture from $\mathrm{CO}_{2} / \mathrm{N}_{2}$ gas stream [26]. The surface area and adsorption capacity were enhanced in comparison with untreated OFA. In the present study, OFA is subjected to an alkaline treatment using ammonium hydroxide solution in an attempt to improve the adsorption capacity of $\mathrm{CO}_{2}$ on the surface through chemisorption in addition to physisorption. The performances of the amine-treated and nontreated OFA are compared. The previous work discussed the synthesis of the adsorbent and in this study the focus is on the kinetics and thermodynamics of $\mathrm{CO}_{2}$ sorption onto the alkaline treated OFA. Further, the $\mathrm{CO}_{2}$ sorption on alkaline-treated OFA is modeled.

\section{Methods}

2.1. Materials. The OFA used in this study was produced by local electric power generation plants. Ammonium hydroxide solution ( $30 \% \mathrm{NH}_{3}$ in water, Sigma-Aldrich) was used for the chemical treatment and had a density of $0.9 \mathrm{~g} / \mathrm{mL}$ at $25^{\circ} \mathrm{C}$ and a purity of $\geq 99.99 \%$. A portable $\mathrm{CO}_{2}$ meter (from TESTO $\mathrm{CO}_{2}$ ) and GC-MS (Agilent Technologies) were used to measure the $\mathrm{CO}_{2}$ outlet concentrations and relative humidity was measured by a relative humidity meter at the bed inlet and outlet. Deionized water and soap were used to wash all glassware to remove any adhered impurities.

2.2. Activation of OFA. Ammonium hydroxide solution was used for the activation of OFA. A representative sample of $100 \mathrm{~g}$ of the ash was mixed thoroughly with $300 \mathrm{~mL}$ of ammonium hydroxide solution at room temperature and then transferred to a $500 \mathrm{~mL}$ flask and refluxed at $120^{\circ} \mathrm{C}$ for $24 \mathrm{~h}$ using a temperature ramp of $1^{\circ} \mathrm{C} / \mathrm{min}$. The mixture was cooled, after which $150 \mathrm{~mL}$ of ammonium hydroxide was added and mixed for another $24 \mathrm{~h}$. The resultant mixture was filtered and the filter cake was dried in the oven at $105^{\circ} \mathrm{C}$ for $4 \mathrm{~h}$ and then left to cool at room temperature. The presence of amine functional groups on the OFA surface (as a result of ammonium hydroxide treatment) was confirmed by FTIR analysis of the final product.

\subsection{Characterization and Analysis of OFA and Activated OFA.} The morphology of OFA was characterized by scanning electron microscopy (SEM) on a JEOL JSM 6400 scanning electron microscope. Prior to analysis at different magnifications, the samples were coated with carbon. The surface area was determined by nitrogen adsorption at $77 \mathrm{~K}$ on a Micrometrics 2020 instrument. Prior to analysis, the samples were degassed under vacuum and dried at $150^{\circ} \mathrm{C}$ for $6 \mathrm{~h}$. A PerkinElmer FTIR spectrophotometer was used to analyze the functional groups of the samples.

\subsection{Adsorption Studies}

2.4.1. Adsorption Isotherm Study. First the adsorption isotherm of $\mathrm{CO}_{2}$ was measured at different initial pressure values using a magnetic suspension balance (Robotherm). A sample of approximately $0.35 \mathrm{~g}$ of OFA was degassed at $100^{\circ} \mathrm{C}$ for $5 \mathrm{~h}$ and subjected to a buoyancy measurement using helium at $25^{\circ} \mathrm{C}$. The adsorption isotherm was obtained by measuring the equilibrium weight of the sample at $25^{\circ} \mathrm{C}$ at various equilibrium pressures of pure carbon dioxide (1-40 bar).

2.4.2. Adsorption Kinetics Study. Next, we measured kinetics parameters including the initial $\mathrm{CO}_{2}$ concentration (363 and $795 \mathrm{ppm})$, flow rate $(0.3,0.7$, and $1.0 \mathrm{~mL} / \mathrm{min})$, humidity (20\% and $60 \% \mathrm{RH})$, and bed temperature $\left(-20\right.$ to $\left.40^{\circ} \mathrm{C}\right)$ using a jacketed quartz adsorption column $(18 \mathrm{~cm}$ in length and $1.0 \mathrm{~cm}$ in diameter), whereby a glycol/water mixture was circulated through the jacket to maintain isothermal conditions using a PID temperature controller (Figure 1). A representative sample of $1.5 \mathrm{~g}$ of activated OFA was placed in the adsorption column. Nitrogen was then introduced into the bed and the concentration of $\mathrm{CO}_{2}$ was measured to ensure that no $\mathrm{CO}_{2}$ was initially present in the ash sample. Subsequently, a $\mathrm{CO}_{2} / \mathrm{N}_{2}$ mixture was introduced into the column at different flow rates, concentrations, temperatures, and relative humidities. At the same time, the concentration of $\mathrm{CO}_{2}$ exiting the column was measured at different time intervals. The relative humidity was measured at the inlet and outlet of the column. $\mathrm{N}_{2}$ gas was used in the desorption 


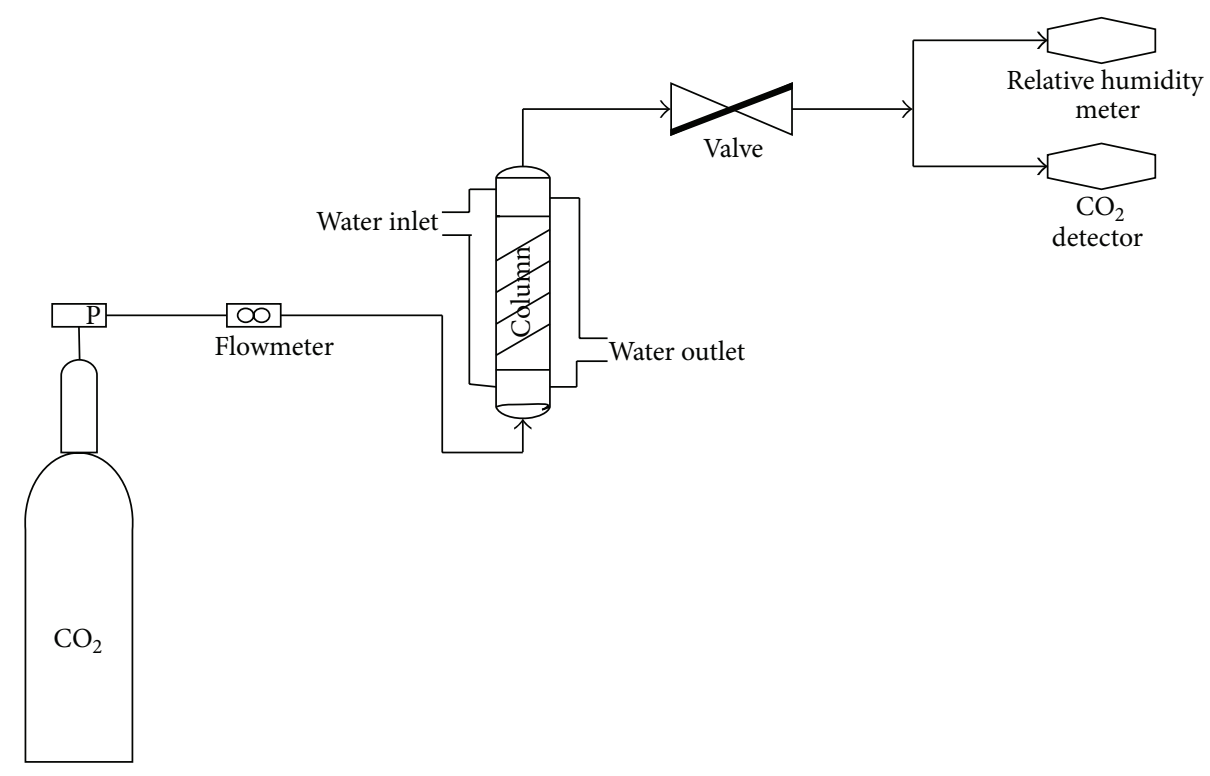

FIgURE 1: Apparatus used for the adsorption kinetics study.

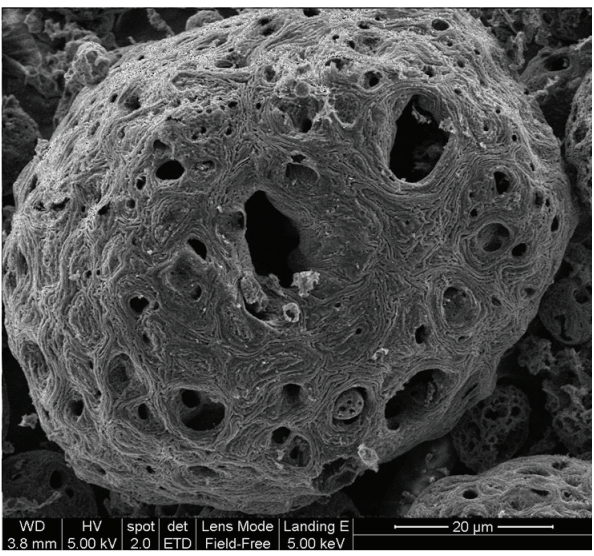

(a)

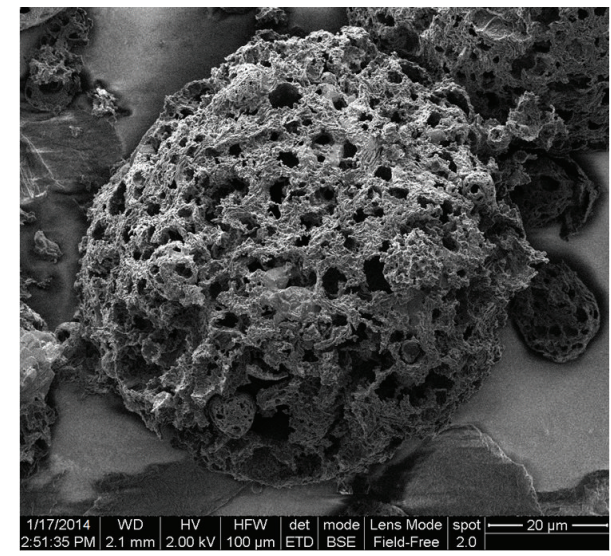

(b)

FIgURE 2: SEM images of OFA (a) before and (b) after chemical treatment.

experiments following the same procedure as that used for the adsorption experiments.

\section{Results and Discussion}

3.1. Characterization of Activated Fly Ash. The SEM images of the untreated and treated OFA samples are shown in Figure 2. As observed, the ash samples mostly consisted of spherical particles. The untreated ash contained large and small pores, with an average pore diameter of $2-3 \mu \mathrm{m}$. The particle size ranged from 10 to $100 \mu \mathrm{m}$ [27]. In contrast, the morphology of the activated OFA exhibited a well-defined porous structure in which the pores were more open than those present in the original OFA.

The FTIR spectrum of the untreated ash is given in Figure 3. The untreated ash exhibited different peaks at 1123, 1623, 2371, 3307, and $3772 \mathrm{~cm}^{-1}$. These broad peaks were associated with $\mathrm{C}=\mathrm{C}, \mathrm{C}=\mathrm{O}, \mathrm{C}=\mathrm{C}, \mathrm{H}-\mathrm{C}=$, and $\mathrm{O}-\mathrm{H}$ functional groups, respectively. The chemically treated ash displayed a broad peak at $3402 \mathrm{~cm}^{-1}$ that indicated the presence of $-\mathrm{NH}_{2}-$, while the peak at $3186 \mathrm{~cm}^{-1}$ was attributed to $-\mathrm{NH}_{2}$ symmetric and $-\mathrm{NH}_{2}$ asymmetric stretching vibrations [28]. However, after chemical activation, the intensities of the untreated ash peaks at $3772 \mathrm{~cm}^{-1}$ and $3206 \mathrm{~cm}^{-1}$ were reduced to $3402 \mathrm{~cm}^{-1}$ and $3186 \mathrm{~cm}^{-1}$, respectively. At a high alkaline $\mathrm{pH}$, the $\mathrm{OH}$ groups attack the surface of OFA during the activation process. Moreover, during the activation process in hot solution, chemical reactions involving carbon oxidation and hydroxide reduction are expected to occur between OFA and ammonium hydroxide. This reaction results in the expansion of the interlayers of adjacent hexagonal network planes in the OFA structure.

Figure 4 shows the $\mathrm{N}_{2}$ adsorption-desorption isotherms measured at $77 \mathrm{~K}$ of the untreated and chemically treated 
TABLE 1: Surface properties of OFA measured by $\mathrm{N}_{2}$ adsorption analysis at $77 \mathrm{~K}$.

\begin{tabular}{lcccc}
\hline Sample & $\begin{array}{c}\text { BET surface area } \\
\left(\mathrm{m}^{2} / \mathrm{g}\right)\end{array}$ & $\begin{array}{c}\text { Langmuir surface } \\
\text { area }\left(\mathrm{m}^{2} / \mathrm{g}\right)\end{array}$ & $\begin{array}{c}\text { Average pore width } \\
(4 V / A)(\AA)\end{array}$ & $\begin{array}{c}\mathrm{t} \text {-plot micropore } \\
\text { volume }\left(\mathrm{cm}^{3} / \mathrm{g}\right)\end{array}$ \\
\hline OFA before treatment & 59 & 78 & 133 & 0.038 \\
OFA after treatment & 318 & 391 & 147 & 0.678 \\
\hline
\end{tabular}

TABLE 2: Elemental analysis of fly ash by EDX.

\begin{tabular}{|c|c|c|c|c|c|c|}
\hline \multirow{2}{*}{ Element } & \multicolumn{3}{|c|}{ Raw OFA } & \multicolumn{3}{|c|}{ Treated OFA, dried at $105^{\circ} \mathrm{C}$} \\
\hline & Spot 1 & Spot 2 & Spot 3 & Spot 1 & Spot 2 & Spot 3 \\
\hline $\mathrm{C}$ & 92.98 & 92.72 & 92.43 & 93.3 & 93.38 & 93.56 \\
\hline $\mathrm{O}$ & - & - & - & - & - & - \\
\hline S & 5.48 & 5.48 & 5.41 & 4.23 & 4.32 & 4.31 \\
\hline $\mathrm{Si}$ & - & 0.14 & 0.2 & 0.3 & 0.19 & 0.21 \\
\hline $\mathrm{Na}$ & 0.13 & 0.14 & 0.15 & - & - & - \\
\hline $\mathrm{Mg}$ & 0.23 & 0.18 & 0.26 & 0.63 & 0.61 & 0.57 \\
\hline $\mathrm{Ca}$ & 0.26 & 0.2 & 0.37 & 0.27 & 0.25 & 0.25 \\
\hline $\mathrm{V}$ & 0.91 & 0.88 & 0.83 & 0.65 & 0.63 & 0.56 \\
\hline $\mathrm{Fe}$ & - & 0.28 & 0.36 & 0.26 & 0.27 & 0.24 \\
\hline
\end{tabular}

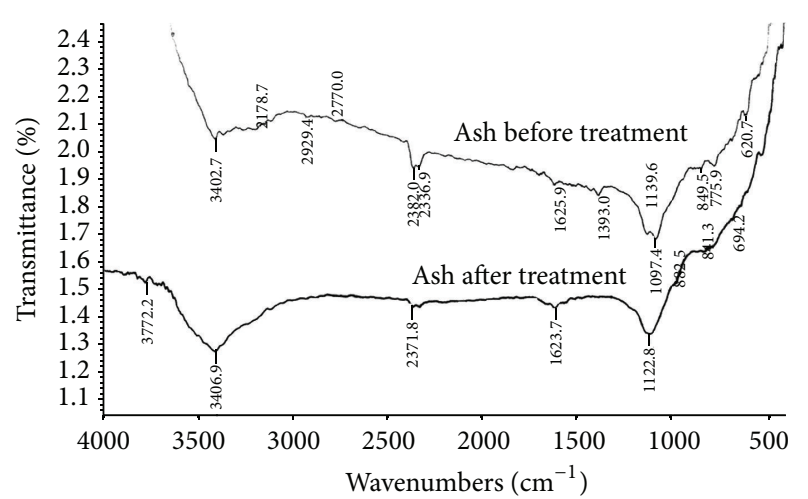

FIGURE 3: FTIR spectra for OFA before and after chemical treatment.

ash samples. The BET surface area increased from $59 \mathrm{~m}^{2} / \mathrm{g}$ for the untreated ash to $318 \mathrm{~m}^{2} / \mathrm{g}$ for the OFA after chemical activation. The pore volume also increased substantially from 0.0368 to $0.6786 \mathrm{~cm}^{3} / \mathrm{g}$ following chemical activation (Table 1). Reinik et al. subjected OFA to a hydrothermal treatment in the presence of $5 \mathrm{M} \mathrm{NaOH}$. The resulting OFA displayed a high surface area of $67.9 \mathrm{~m}^{2} / \mathrm{g}$ [29]. In a recent study, Mofarrah et al. treated OFA with various oxidizing agents, that is, nitric, hydrochloric, and phosphoric acids, followed by physical activation at $800^{\circ} \mathrm{C}$. The researchers obtained activated OFA with a surface area of $123.19 \mathrm{~m}^{2} / \mathrm{g}$ and a total pore volume of $0.2215 \mathrm{~cm}^{3} / \mathrm{g}$ [30].

Table 2 shows the elemental analysis of OFA before and after chemical treatment. It can be seen that the fly ash before treatment was composed primarily of carbon with some sulfur and traces of heavy metals [31, 32]. Unlike the effects of acid treatment, the alkaline treatment did not result in noticeable changes in the composition of the fly ash.
The sodium in the fly ash either leached out upon treatment or was not detectable by EDX.

3.2. Adsorption Isotherm of $\mathrm{CO}_{2}$ Using Activated OFA. The $\mathrm{CO}_{2}$ adsorption-desorption isotherm of activated OFA obtained at different pressures using the Rubotherm instruments is shown in Figure 5. The amount of $\mathrm{CO}_{2}$ that was adsorbed per gram of OFA was higher than that desorbed at the same equilibrium pressure. A multilayer adsorption process occurred as the equilibrium pressure increased. The difference between the adsorption and desorption curves was related to the amount of $\mathrm{CO}_{2}$ that was chemisorbed onto the OFA surface. Initially, at low equilibrium pressures, a high amount of $\mathrm{CO}_{2}$ was chemisorbed, reaching a maximum value of $17.8 \mathrm{mg} / \mathrm{g}$ at $16 \mathrm{bar}$, followed by a decrease in the uptake of $\mathrm{CO}_{2}$ as the equilibrium pressure was further increased. Increasing the sample pressure increased the concentration of $\mathrm{CO}_{2}$ molecules on the active sites that resulted in more $\mathrm{CO}_{2}$-surface interactions. Further increases in the pressure reduced the amount of $\mathrm{CO}_{2}$ chemisorbed onto the surface, due to consumption of the reactive amine sites and the attainment of the saturation adsorption level in the OFA pores (Figure 6).

The Langmuir, Freundlich, and BET isotherm models were examined to describe the adsorption process and the $\mathrm{CO}_{2}$ adsorption capacity of treated OFA was estimated accordingly.

The Langmuir model describes monolayer coverage on a solid surface as follows:

$$
q=\frac{Q b p}{(1+b p)}
$$

where $\mathrm{Q}(\mathrm{mmol} / \mathrm{g})$ is the maximum amount of $\mathrm{CO}_{2}$ that is adsorbed per unit mass for a complete monolayer, $C_{e}$ is the equilibrium pressure of $\mathrm{CO}_{2}$ (bar), and $b(\mathrm{~L} / \mathrm{mmol})$ is the 


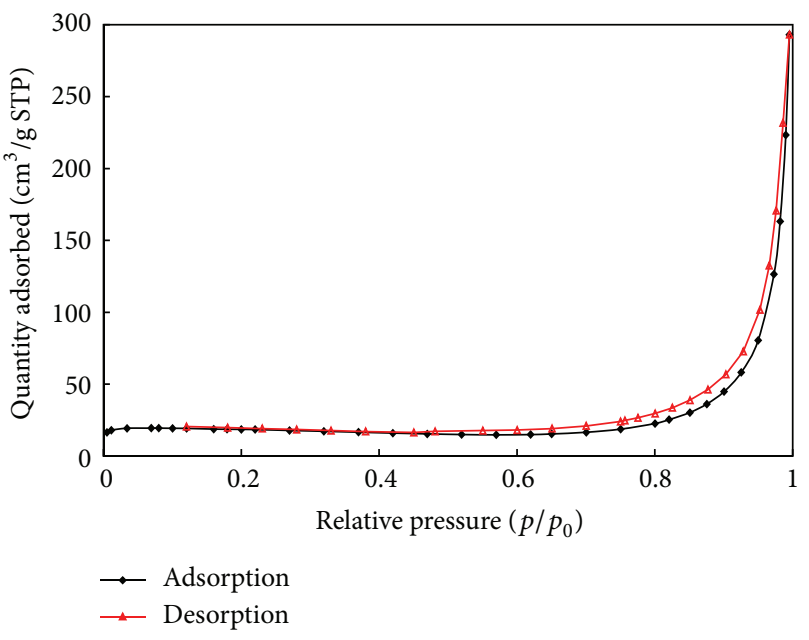

(a)

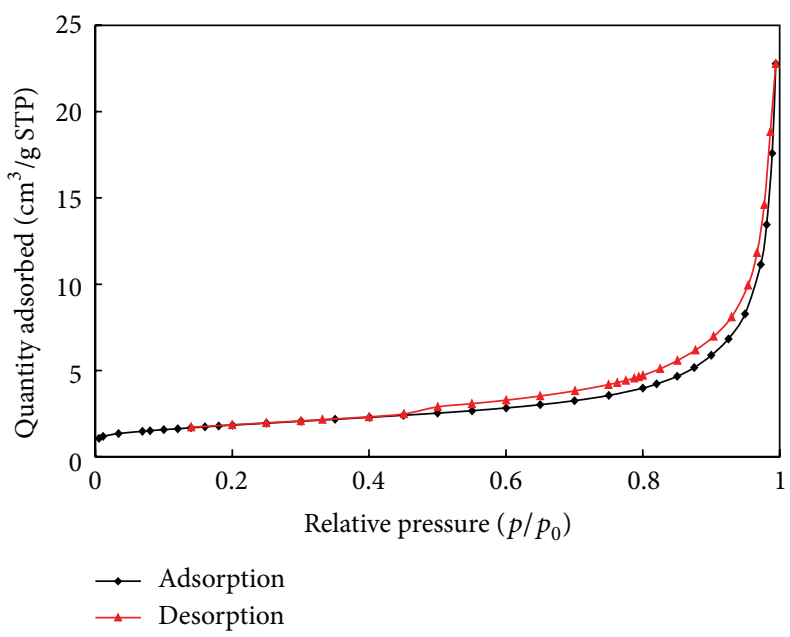

(b)

FIGURE 4: BET surface area analysis (a) before and (b) after acid treatment.

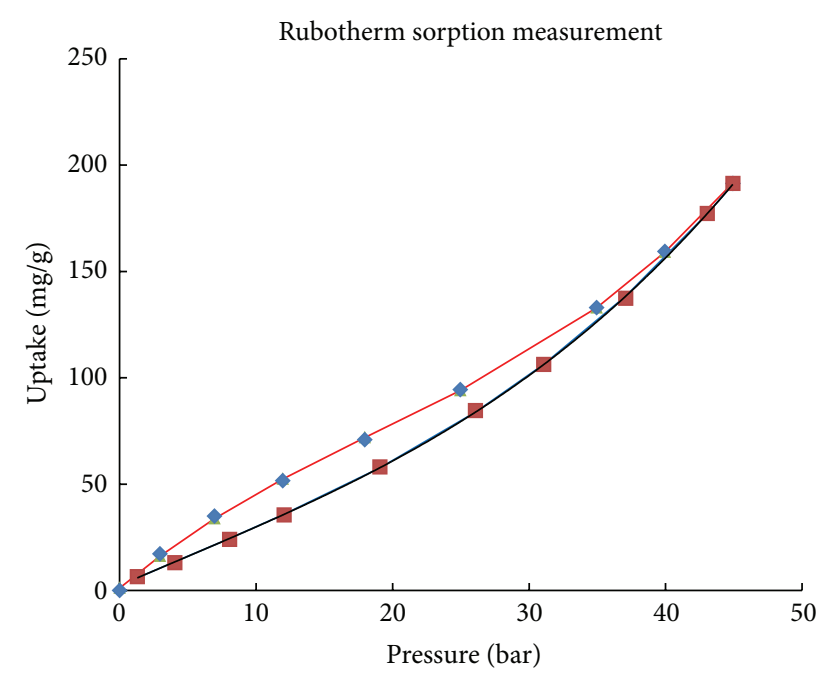

- Adsorption

- Desorption

FIGURE 5: $\mathrm{CO}_{2}$ equilibrium isotherm over treated OFA.

Langmuir constant that is related to the affinity of the binding sites of the adsorbent.

The Freundlich model accounts for surface heterogeneity in the energy and is represented by (4):

$$
q=k p^{b}
$$

where both $k$ and $b$ are constants.

The Sips model is a combination of the Langmuir and Freundlich models. The Sips model incorporates both the effect of surface heterogeneity and the saturation capacity of the adsorbent. At low equilibrium concentrations of the adsorbate, the Sips model reduces to the Freundlich model, whereas at high concentrations the amount of adsorbed

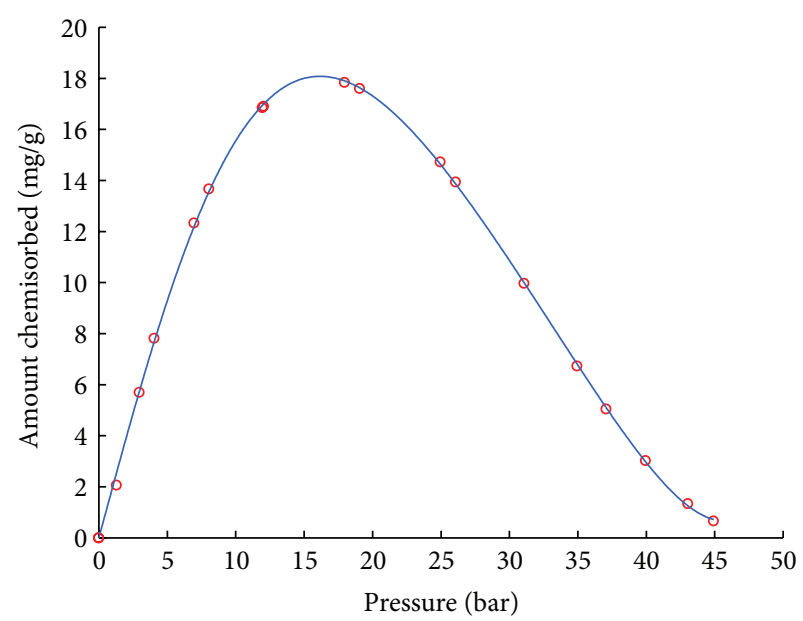

Figure 6: Effect of pressure on the amount of $\mathrm{CO}_{2}$ chemisorbed onto treated OFA.

solutes reaches a plateau at a saturation value, $Q(\mathrm{mmol} / \mathrm{g})$ [33]. The Sips model is described by the following expression:

$$
q=\frac{Q b p^{n}}{\left(1+b p^{n}\right)} .
$$

In the BET model, the formation of multiple layers on the surface of the adsorbent is assumed, thereby achieving a multilayer coverage on the material surface:

$$
q=\frac{Q_{0} a_{1} p}{\left(p_{s}-p\right)\left[1+\left(a_{0}-1\right) p / p_{s}\right]},
$$

where $Q_{0}, a_{1}$, and $p_{s}$ represent the saturation capacity, constant account for difference in adsorption energies between the first layer and higher layers, and saturation pressure for $\mathrm{CO}_{2}$ at the studied system temperature. The corresponding isotherm values were fitted using MATLAB (V. 8.3) and the results are presented in Table 3. Among all the studied 
TABLE 3: Isotherm parameters for the Langmuir, Freundlich, and BET models.

\begin{tabular}{lcc}
\hline Model & Parameters & Values \\
\hline \multirow{3}{*}{ Langmuir } & $Q$ & 652.9 \\
& $b$ & $7.322 \times 10^{-3}$ \\
& $R^{2}$ & 0.968 \\
$x^{2}$ & 1107 \\
\hline \multirow{3}{*}{ Freundlich } & $k$ & 10.53 \\
& $b$ & 0.714 \\
& $R^{2}$ & 0.953 \\
& $x^{2}$ & 1635 \\
\hline \multirow{3}{*}{ Sips } & $Q_{s}$ & 540.3 \\
& $k_{s}$ & $6.210 \times 10^{-3}$ \\
& $n_{s}$ & 1.142 \\
& $R^{2}$ & 0.982 \\
BET & $x^{2}$ & 619 \\
\hline & $Q_{0}$ & 74.51 \\
& $a_{1}$ & 5.975 \\
& $a_{2}$ & 67.05 \\
& $R^{2}$ & 0.990 \\
& $x^{2}$ & 344 \\
\hline
\end{tabular}

isotherm models, the BET model best fits the adsorption data. The model generated a high regression coefficient of 0.990 and the lowest sum of square errors of 13.44. The saturation adsorption capacity determined from the BET model, which corresponds to a monolayer of adsorption in pressure range $0.05<p / p_{s}<0.35$, was $74.51 \mathrm{mg} / \mathrm{g}$ of ash. The saturation capacity determined from the Sips model which corresponds to the sum of the saturation capacities of all of the adsorbed layers was $540.3 \mathrm{mg} / \mathrm{g}$ of ash.

3.3. Analysis of the Adsorption Kinetics. The rate of adsorption was determined by passing $\mathrm{CO}_{2}$ through the adsorption column at fixed initial concentrations and relative humidity and monitoring the concentration of $\mathrm{CO}_{2}$ exiting the column as a function of time. Kinetics parameters, namely, the bed temperature, gas flow rate, and concentration and humidity, were investigated. Desorption experiments were performed in the same manner as the adsorption measurements, except that pure and dry $\mathrm{N}_{2}$ gas was used.

Figure 7 shows the breakthrough curves obtained using $1.5 \mathrm{~g}$ of treated OFA, an initial $\mathrm{CO}_{2}$ concentration of $350 \mathrm{mg} / \mathrm{L}$, and a $\mathrm{CO}_{2} / \mathrm{N}_{2}$ flow rate of $0.3 \mathrm{~L} / \mathrm{min}$ and at $20 \%$ relative humidity $(\mathrm{RH}), 1 \mathrm{~atm}$, and $22^{\circ} \mathrm{C}$. The areas above the adsorption and desorption curves correspond to the adsorbed and desorbed amounts of $\mathrm{CO}_{2}$, respectively. The area between the two curves corresponds to the amount (in $\mathrm{mg}$ ) of $\mathrm{CO}_{2}$ that remained on the OFA surface. The trapezoidal rule was used to estimate the amounts of adsorbed $(0.238 \mathrm{mg} / \mathrm{g})$ and desorbed $(0.115 \mathrm{mg} / \mathrm{g}) \mathrm{CO}_{2}$ at atmospheric pressure. The difference of $0.123 \mathrm{mg} / \mathrm{g}$ between the aforementioned values corresponded to the amount of $\mathrm{CO}_{2}$ that was chemisorbed onto the ash bed.

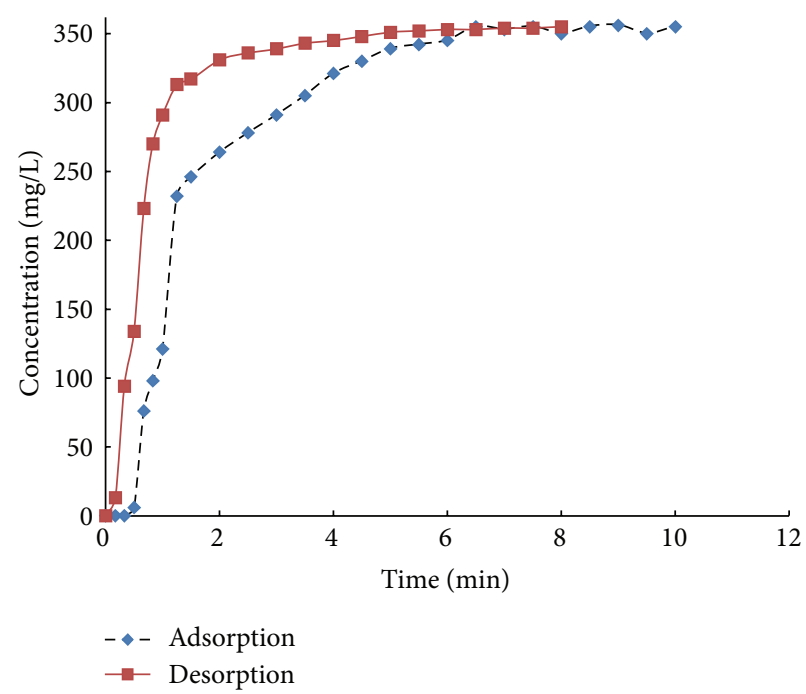

FIgURE 7: Adsorption-desorption curves for $\mathrm{CO}_{2}$. Reaction conditions: initial $\mathrm{CO}_{2}$ concentration of $350 \mathrm{mg} / \mathrm{L}, \mathrm{CO}_{2} / \mathrm{N}_{2}$ flow rate of $0.3 \mathrm{~L} / \mathrm{min}, 1.5 \mathrm{~g}$ ash, $20 \% \mathrm{RH}, 1 \mathrm{~atm}$, and $22^{\circ} \mathrm{C}$.

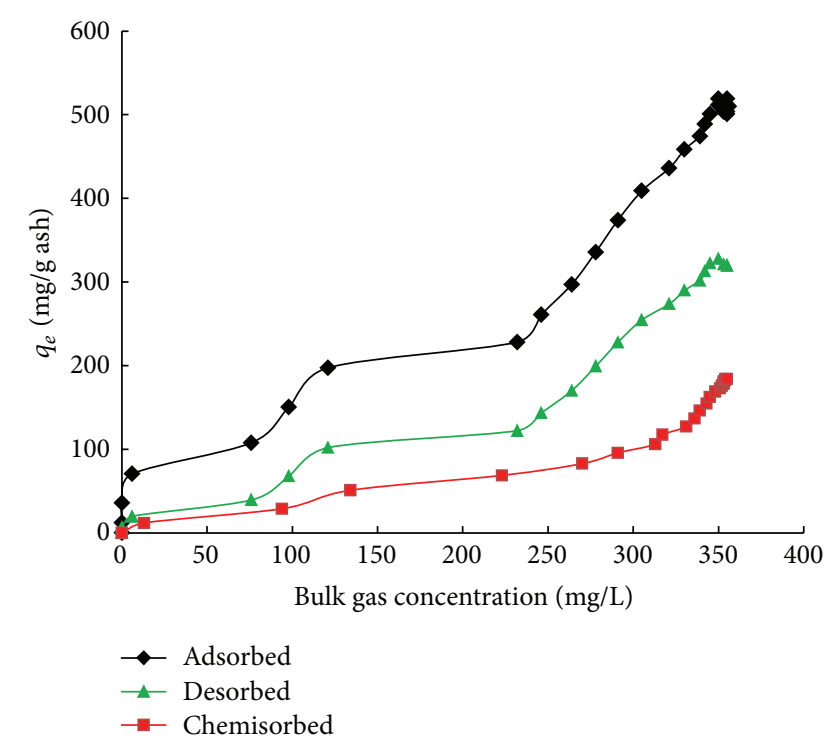

FIGURE 8: Effect of initial $\mathrm{CO}_{2}$ concentration on the amount of $\mathrm{CO}_{2}$ adsorbed, desorbed, and chemisorbed. Reaction conditions: $\mathrm{CO}_{2} / \mathrm{N}_{2}$ flow rate of $0.3 \mathrm{~L} / \mathrm{min}, 1.5 \mathrm{~g}$ ash, $20 \% \mathrm{RH}$, and $22^{\circ} \mathrm{C}$.

3.3.1. Effect of Initial $\mathrm{CO}_{2}$ Concentration. Further results on the effect of the initial $\mathrm{CO}_{2}$ concentration are shown in Figures 8 and 9. The OFA adsorption capacity increased with increasing $\mathrm{CO}_{2}$ concentrations $[34,35]$ because of the increase in driving force between the bulk concentration and the concentration at the particle surface, thereby promoting mass transfer. However, when the ash surface was saturated, further increases in the $\mathrm{CO}_{2}$ concentration did not further improve the adsorption capacity. This activated OFA reached its saturation capacity at higher concentrations quickly. Thus, the saturation time decreased as the adsorbate concentration increased $[36,37]$. 


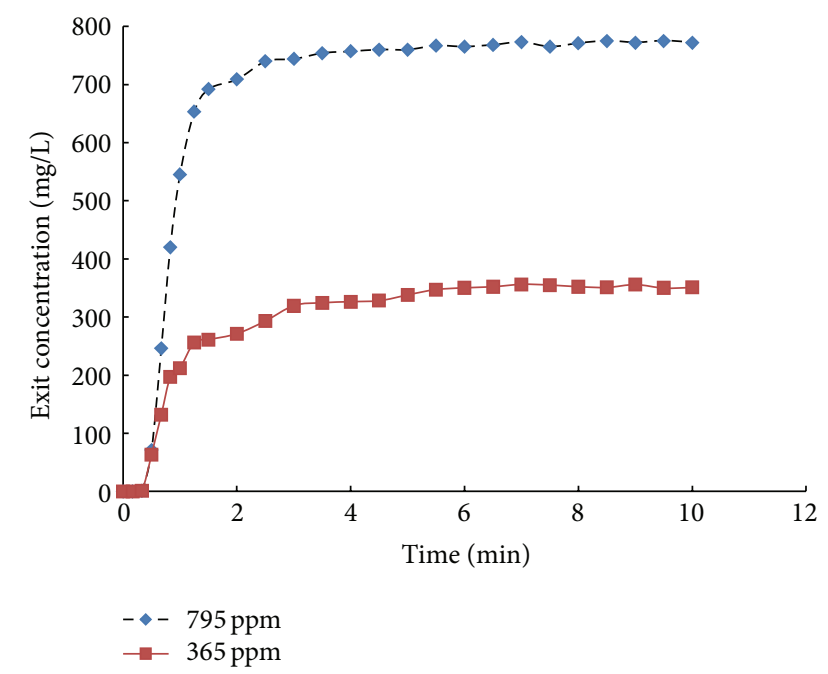

FIGURE 9: Effect of initial $\mathrm{CO}_{2}$ concentration on adsorption. Reaction conditions: $\mathrm{CO}_{2} / \mathrm{N}_{2}$ flow rate of $0.3 \mathrm{~L} / \mathrm{min}, 1.5 \mathrm{~g}$ ash, $20 \% \mathrm{RH}$, and $22^{\circ} \mathrm{C}$.

3.3.2. Effect of Flow Rate. The effect of the gas flow rate was studied at two different $\mathrm{CO}_{2}$ concentrations, $795 \mathrm{ppm}$ and $365 \mathrm{ppm}$, at both low and high humidities. The effect of the $\mathrm{CO}_{2}$ flow rate was studied using flow rates of $0.3,0.7$, and $1.5 \mathrm{~mL} / \mathrm{min}$. Figure 10 shows that increasing the $\mathrm{CO}_{2}$ flow rate reduced the time required to reach the maximum adsorption capacity. Hence, the residence time of the gas in the ash bed decreased [34]. Increasing the gas flow rate increased the diffusion rate of the $\mathrm{CO}_{2}$ molecules to the particle surface. In addition, the rate of mass transfer in the gas film was likely enhanced because of the reduction in the external mass transfer resistance and the saturation time $[38,39]$. It has also been reported $[39,40]$ that the application of $\mathrm{CO}_{2}$ at high pressures increases the strength of the interaction between amine and $\mathrm{CO}_{2}$ molecules, which favors the chemical reaction and increases the extent of chemisorption.

3.3.3. Effect of Humidity. The effect of relative humidity ( $10 \%$ and $80 \%$ ) on the adsorption of $\mathrm{CO}_{2}$ onto treated fly ash is shown in Figure 11. A decrease in the adsorption capacity at the higher relative humidity was observed. This result can be explained by consideration of the capillary condensation of water vapor in the pores of the ash; at $80 \% \mathrm{RH}$, a large portion of the active sites on the surface of these pores are blocked [41, 42]. Increasing the humidity decreases the partial pressure of $\mathrm{CO}_{2}$ in the gas phase and leads to water vapor competing with $\mathrm{CO}_{2}$ molecules to reach the surface. When water condensation dominates over evaporation, there is competition between these two species for adsorption onto the active OFA sites. This was confirmed by measuring the $\mathrm{RH}$ at the column's exit; a $2 \%$ decrease in relative humidity was observed. Increasing the adsorption capacity could be achieved by increasing the temperature while reducing the humidity, thus opening up the mesopores [43].

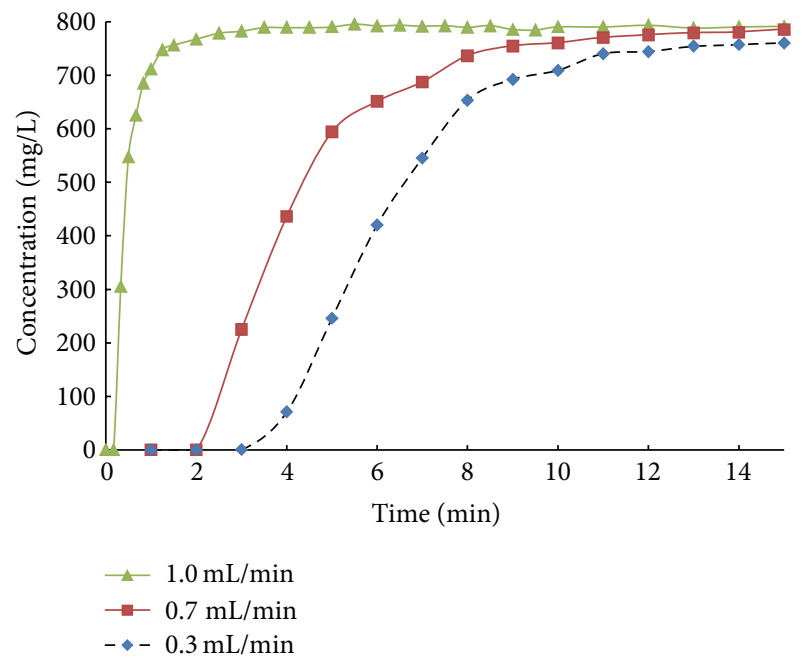

FIGURE 10: Effect of flow rate on adsorption of $\mathrm{CO}_{2}$ onto fly ash. Reaction conditions: initial $\mathrm{CO}_{2}$ concentration of $795 \mathrm{ppm}, 1.5 \mathrm{~g}$ ash, $20 \% \mathrm{RH}$, and $22^{\circ} \mathrm{C}$.

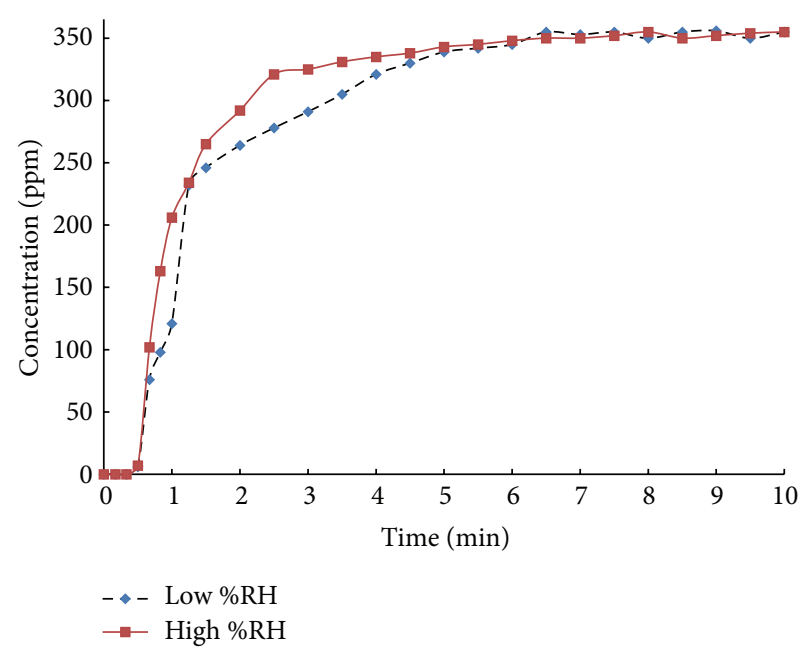

FIGURE 11: Effect of humidity on adsorption of $\mathrm{CO}_{2}$ (high $\% \mathrm{RH}=$ $80 \%$ and low $\% \mathrm{RH}=10 \%$ ) onto fly ash. Reaction conditions: initial $\mathrm{CO}_{2}$ concentration of $350 \mathrm{ppm}, \mathrm{CO}_{2} / \mathrm{N}_{2}$ flow rate of $0.3 \mathrm{~L} / \mathrm{min}, 1 \mathrm{~g}$ ash, and $22^{\circ} \mathrm{C}$.

3.3.4. Effect of Temperature. Next, we investigated the effects of bed temperatures of $-20,-10,0,10,20,30$, and $40^{\circ} \mathrm{C}$ on the rate of $\mathrm{CO}_{2}$ adsorption onto treated OFA. We found that the adsorption rate of $\mathrm{CO}_{2}$ increased up to a break-even point as the bed and inlet gas temperatures increased (Figure 12). This demonstrates the endergonic nature of the interaction between the gas molecules and the ash surface at which both physical and chemical adsorption occurred. Moreover, there was a direct link between increases in the temperature and the pressure drop across the bed [44].

Equations (1) and (2) were used to determine thermodynamic parameters such as the heat of adsorption, standard 
TABLE 4: Thermodynamic parameters for $\mathrm{CO}_{2}$ adsorption onto treated fly ash.

\begin{tabular}{|c|c|c|c|c|}
\hline \multirow{2}{*}{$T\left({ }^{\circ} \mathrm{C}\right)$} & \multicolumn{2}{|c|}{ Low relative humidity } & \multicolumn{2}{|c|}{ High relative humidity } \\
\hline & $K_{c}$ & $\Delta G_{\text {ads }}(\mathrm{kJ} / \mathrm{mol})$ & $K_{c}$ & $\Delta G_{\mathrm{ads}}(\mathrm{kJ} / \mathrm{mol})$ \\
\hline $\begin{array}{ll}-10 \\
\end{array}$ & $3.95 \times 10^{-2}$ & $-6.82 \times 10^{2}$ & $3.08 \times 10^{-6}$ & $-26.69 \times 10^{2}$ \\
\hline-20 & $2.89 \times 10^{-1}$ & $-2.72 \times 10^{2}$ & $7.82 \times 10^{-5}$ & $-20.68 \times 10^{2}$ \\
\hline 0 & $1.00 \times 10^{2}$ & $4.55 \times 10^{-3}$ & $2.36 \times 10^{-4}$ & $-18.95 \times 10^{2}$ \\
\hline 10 & $8.26 \times 10^{2}$ & $4.98 \times 10^{2}$ & $4.46 \times 10^{-2}$ & $-7.32 \times 10^{2}$ \\
\hline 20 & $15.32 \times 10^{2}$ & $6.07 \times 10^{2}$ & $1.66 \times 10^{-1}$ & $-4.37 \times 10^{2}$ \\
\hline 30 & $39.92 \times 10^{2}$ & $9.32 \times 10^{2}$ & $3.74 \times 10^{1}$ & $3.34 \times 10^{2}$ \\
\hline 40 & $48.09 \times 10^{2}$ & $10.11 \times 10^{2}$ & $25.10 \times 10^{2}$ & $8.39 \times 10^{2}$ \\
\hline$\Delta H_{\mathrm{ads}}(\mathrm{kJ} / \mathrm{mol})$ & \multicolumn{2}{|c|}{80} & \multicolumn{2}{|c|}{178} \\
\hline$\Delta S_{\mathrm{ads}}(\mathrm{J} / \mathrm{mol} \cdot \mathrm{K})$ & \multicolumn{2}{|c|}{296} & \multicolumn{2}{|c|}{597} \\
\hline
\end{tabular}

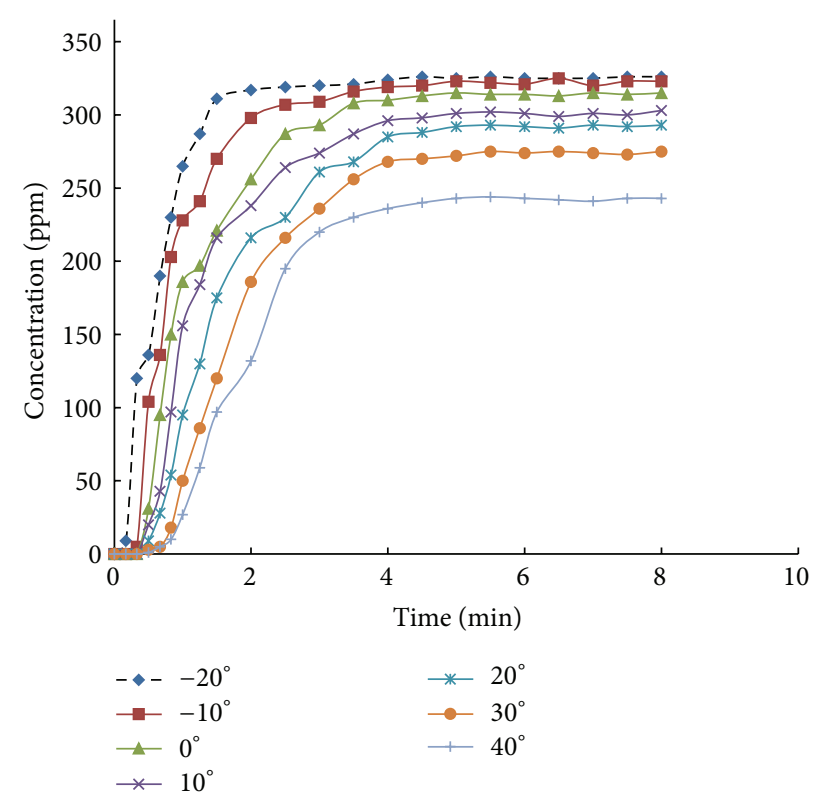

FigURE 12: Effect of bed temperature on adsorption of $\mathrm{CO}_{2}$ onto treated ash. Reaction conditions: initial $\mathrm{CO}_{2}$ concentration of $350 \mathrm{ppm}, \mathrm{CO}_{2} / \mathrm{N}_{2}$ flow rate of $0.3 \mathrm{~L} / \mathrm{min}, 1 \mathrm{~g}$ ash, and $10 \% \mathrm{RH}$.

entropy, and standard free energy of the adsorption process [45-47]:

$$
\begin{aligned}
\Delta G_{\mathrm{ads}}^{0} & =-R T \ln K_{c}, \\
\ln K_{c} & =\frac{\Delta S_{\mathrm{ads}}^{0}}{R}-\frac{\Delta H_{\mathrm{ads}}^{0}}{R T}, \\
K_{c} & =\frac{q_{e}}{C_{e}^{b}},
\end{aligned}
$$

where $\Delta H_{\text {ads }}^{0}$ is the heat of adsorption, $\Delta S_{\text {ads }}^{0}$ is the standard entropy, $\Delta G_{\text {ads }}^{0}$ is the standard Gibbs free energy, and $q_{e}$ and $C_{e}$ are the adsorbed and solution equilibrium adsorption values, respectively. $R$ is the gas constant $(8.314 \mathrm{~J} / \mathrm{mol} \mathrm{K})$.

The heat of adsorption and the standard entropy were obtained by plotting $\ln K_{c}$ versus $1 / T$ at both low and high humidity (Figure 13). $\Delta H_{\text {ads }}^{0}$ and $\Delta S_{\text {ads }}^{0}$ were calculated from the slope and the intercept of the plot, respectively [27, 45-50].

As the temperature increased, both $K_{c}$ and the adsorption capacity increased, which could be attributed to the increase in the number of active surface sites that were available for adsorption. Additionally, the motion of $\mathrm{CO}_{2}$ molecules on the ash surface increased owing to increases in the temperature [27]. The calculated values of $\Delta H_{\mathrm{ads}}, \Delta S_{\mathrm{ads}}$, and $\Delta G_{\mathrm{ads}}$ are listed in Table 4 . The positive value of $\Delta H_{\text {ads }}$ at a fixed $\mathrm{RH}$ indicated that the adsorption process was endothermic $[45,50]$. The positive value of $\Delta S_{\text {ads }}$ showed the affinity of the chemically treated fly ash for $\mathrm{CO}_{2}$ (adsorption) and the increasing randomness during the adsorption process [51]. The negative values of $\Delta G_{\text {ads }}$ at -10 and $-20^{\circ} \mathrm{C}$ indicate the spontaneous nature of the adsorption of $\mathrm{CO}_{2}$ onto the fly ash sample [49]. Positive $\Delta G_{\text {ads }}$ values were observed at 0,10 , 20,30 , and $40^{\circ} \mathrm{C}$, indicating that spontaneity was not favored at high temperatures where the thermal energy exceeded the adsorption energy. A similar trend was observed for the adsorption/removal of Congo Red from water using activated carbon that was prepared from coir pith [50]. Moreover, $\Delta G_{\text {ads }}$ increased with increasing temperatures, further indicating that the reaction was endothermic [52].

\section{Conclusions}

We suggest that waste OFA, which is primarily composed of unburned carbon, can be used as a low-cost adsorbent for the removal of $\mathrm{CO}_{2}$ from a gas stream. Promising results were obtained using chemically treated waste OFA for $\mathrm{CO}_{2}$ adsorption. An ammonium hydroxide solution was used to chemically modify fly ash to improve its $\mathrm{CO}_{2}$ adsorption capacity. The BET surface area of OFA increased from $59 \mathrm{~m}^{2} / \mathrm{g}$ to $318 \mathrm{~m}^{2} / \mathrm{g}$ after chemical treatment. Studies of the underlying kinetics showed that the adsorption capacity increases with flow rate, concentration, and temperature. Humidity also strongly influences $\mathrm{CO}_{2}$ adsorption. Thermodynamic studies revealed the heat of adsorption to be 80 and $178 \mathrm{~kJ} / \mathrm{mol}$ at low $(20 \%)$ and high $(80 \%)$ relative humidity, respectively, indicating that the process was endothermic. This indicated that the adsorption of $\mathrm{CO}_{2}$ in alkaline treated OFA is sensitive to humidity and suggests the competitiveness between water vapor and $\mathrm{CO}_{2}$ adsorption on the surface. 


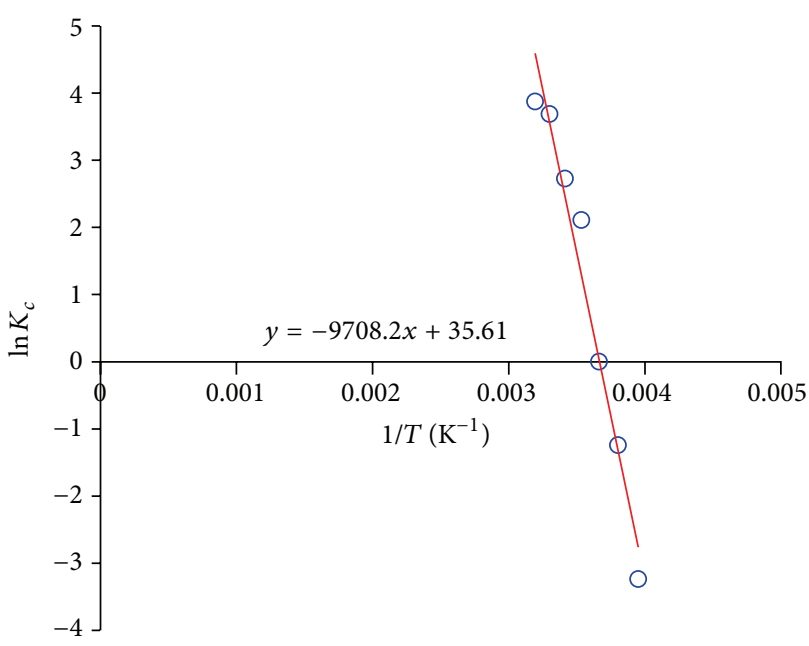

(a)

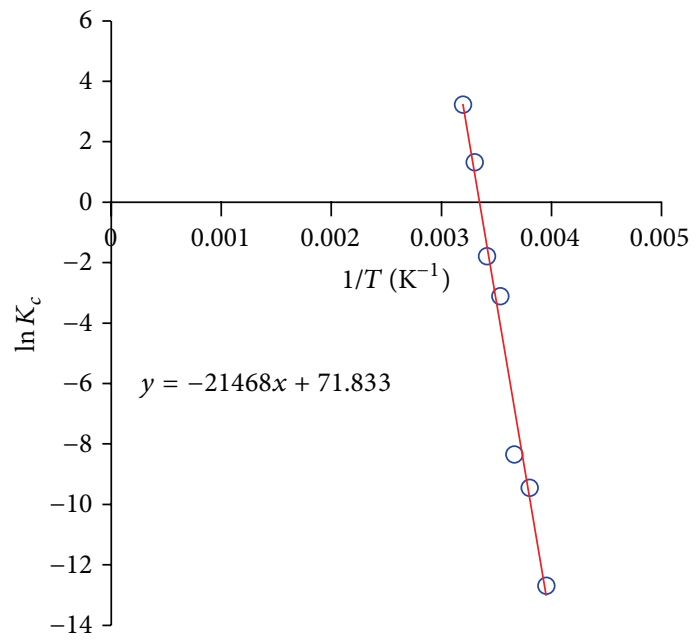

(b)

FIGURE 13: Determination of the heat of adsorption at (a) $\mathrm{CO}_{2}$ flow rate $=0.3 \mathrm{~L} / \mathrm{min}, \% \mathrm{RH}=20 \%$, and initial $\mathrm{CO}_{2}$ concentration $=365 \mathrm{ppm}$ and (b) $\mathrm{CO}_{2}$ flow rate $=0.3 \mathrm{~L} / \mathrm{min}, \% \mathrm{RH}=80 \%$, and initial $\mathrm{CO}_{2}$ concentration $=365 \mathrm{ppm}$.

A variety of isotherm models were studied to obtain the saturation capacity of the treated OFA and it was found that $540.3 \mathrm{mg} / \mathrm{g}$ can be predicted using Sips model, and $652.9 \mathrm{mg} / \mathrm{g}$ is achieved by Langmuir model with regression coefficients 0.982 and 0.968 , respectively. The activated carbonaceous material presented herein is a promising and economically feasible $\mathrm{CO}_{2}$ adsorbent because of its low cost and high sorption capacity.

\section{Conflict of Interests}

The authors declare that there is no conflict of interests regarding the publication of this paper.

\section{Acknowledgments}

The authors would like to acknowledge financial support from King Abdul Aziz City for Science and Technology (KACST) through the Science and Technology Unit at King Fahd University of Petroleum \& Minerals (KFUPM), under Project no. 11-ENV1645-04. The Gas Processing Center at Qatar University is also acknowledged for contributing to the analysis and characterization of the studied material.

\section{References}

[1] M. S. Shafeeyan, W. M. A. W. Daud, A. Houshmand, and A. Shamiri, "A review on surface modification of activated carbon for carbon dioxide adsorption," Journal of Analytical and Applied Pyrolysis, vol. 89, no. 2, pp. 143-151, 2010.

[2] S. D. Kenarsari, D. Yang, G. Jiang et al., "Review of recent advances in carbon dioxide separation and capture," RSC Advances, vol. 3, no. 45, pp. 22739-22773, 2013.

[3] S.-Y. Lee and S.-J. Park, "A review on solid adsorbents for carbon dioxide capture," Journal of Industrial and Engineering Chemistry, vol. 23, pp. 1-11, 2015.
[4] S. S. Warudkar, K. R. Cox, M. S. Wong, and G. J. Hirasaki, "Influence of stripper operating parameters on the performance of amine absorption systems for post-combustion carbon capture. Part I. High pressure strippers," International Journal of Greenhouse Gas Control, vol. 16, pp. 342-350, 2013.

[5] S. Satyapal, T. Filburn, J. Trela, and J. Strange, "Performance and properties of a solid amine sorbent for carbon dioxide removal in space life support applications," Energy \& Fuels, vol. 15, no. 2, pp. 250-255, 2001.

[6] M. S. Shafeeyan, W. M. A. W. Daud, A. Houshmand, and A. Arami-Niya, "Ammonia modification of activated carbon to enhance carbon dioxide adsorption: effect of pre-oxidation," Applied Surface Science, vol. 257, no. 9, pp. 3936-3942, 2011.

[7] I. A. W. Tan, A. L. Ahmad, and B. H. Hameed, "Enhancement of basic dye adsorption uptake from aqueous solutions using chemically modified oil palm shell activated carbon," Colloids and Surfaces A: Physicochemical and Engineering Aspects, vol. 318, no. 1-3, pp. 88-96, 2008.

[8] J. Tomeczek and H. Palugniok, "Kinetics of mineral matter transformation during coal combustion," Fuel, vol. 81, no. 10, pp. 1251-1258, 2002.

[9] Z. Yong, V. G. Mata, and A. E. Rodrigues, "Adsorption of carbon dioxide on chemically modified high surface area carbon-based adsorbents at high temperature," Adsorption, vol. 7, no. 1, pp. 4150, 2001.

[10] A. Arenillas, K. M. Smith, T. C. Drage, and C. E. Snape, " $\mathrm{CO}_{2}$ capture using some fly ash-derived carbon materials," Fuel, vol. 84, no. 17, pp. 2204-2210, 2005.

[11] J. M. de Andrés, L. Orjales, A. Narros, M. D. M. de la Fuente, and M. E. Rodríguez, "Carbon dioxide adsorption in chemically activated carbon from sewage sludge," Journal of the Air and Waste Management Association, vol. 63, no. 5, pp. 557-564, 2013.

[12] J. Weitkamp, "Zeolites and catalysis," Solid State Ionics, vol. 131, no. 1, pp. 175-188, 2000.

[13] M. Al-Harahsheh, R. Shawabkeh, M. Batiha, A. Al-Harahsheh, and K. Al-Zboon, "Sulfur dioxide removal using natural zeolitic tuff," Fuel Processing Technology, vol. 126, pp. 249-258, 2014. 
[14] A. Ramli, S. Ahmed, and S. Yusup, "Adsorption behaviour of Si-MCM-41 for $\mathrm{CO}_{2}$ : effect of pressure and temperature on adsorption," Chemical Engineering Transactions, vol. 39, pp. 271276, 2014.

[15] T. D. Pham, M. R. Hudson, C. M. Brown, and R. F. Lobo, "Molecular basis for the high $\mathrm{CO}_{2}$ adsorption capacity of chabazite zeolites," ChemSusChem, vol. 7, no. 11, pp. 3031-3038, 2014.

[16] Z. T. Yao, X. S. Ji, P. K. Sarker et al., "A comprehensive review on the applications of coal fly ash," Earth-Science Reviews, vol. 141, pp. 105-121, 2015.

[17] C. J. O' Flynn, O. Fenton, and M. G. Healy, "Evaluation of amendments to control phosphorus losses in runoff from pig slurry applications to land," CLEAN-Soil, Air, Water, vol. 40, no. 2, pp. 164-170, 2012.

[18] N. Tanigaki, K. Manako, and M. Osada, "Co-gasification of municipal solid waste and material recovery in a large-scale gasification and melting system," Waste Management, vol. 32, no. 4, pp. 667-675, 2012.

[19] H. Xu, Q. Shao, J. Zhou, and X. Ma, "Study on preparation of water treatment ceramic particles by using sludge and fly ash and the ceramic particles' application," Advanced Materials Research, vol. 356-360, pp. 1876-1881, 2012.

[20] Noor-ul-Amin, "A multi-directional utilization of different ashes," RSC Advances, vol. 4, no. 107, pp. 62769-62788, 2014.

[21] M. Ahmaruzzaman, "Role of fly ash in the removal of organic pollutants from wastewater," Energy \& Fuels, vol. 23, no. 3, pp. 1494-1511, 2009.

[22] M. Ahmaruzzaman, Advanced Materials Research, vol. 955-959, 2014.

[23] W. Astuti, A. Prasetya, E. T. Wahyuni, and I. M. Bendiyasa, "The adsorption of lead from aqueous solutions using coal fly ash: effect of crystallinity," World Academy of Science, Engineering and Technology, vol. 78, pp. 805-810, 2011.

[24] M. Mercedes Maroto-Valer, Z. Lu, Y. Zhang, and Z. Tang, "Sorbents for $\mathrm{CO}_{2}$ capture from high carbon fly ashes," Waste Management, vol. 28, no. 11, pp. 2320-2328, 2008.

[25] K. K. Panday, G. Prasad, and V. N. Singh, "Copper(II) removal from aqueous solutions by fly ash," Water Research, vol. 19, no. 7, pp. 869-873, 1985.

[26] A. L. Yaumi, I. A. Hussien, and R. A. Shawabkeh, "Surface modification of oil fly ash and its application in selective capturing of carbon dioxide," Applied Surface Science, vol. 266, pp. 118-125, 2013.

[27] R. Shawabkeh, "Equilibrium study and kinetics of $\mathrm{Cu}^{2+}$ removal from water by zeolite prepared from oil shale ash," Process Safety and Environmental Protection, vol. 87, no. 4, pp. 261-266, 2009.

[28] A. Sumayya, C. Yohannan Panicker, H. T. Varghese, and B. Harikumar, "Vibrational spectroscopic studies and AB initio calculations of L-glutamic acid 5-amide," Rasayan Journal of Chemistry, vol. 1, no. 3, pp. 548-555, 2008.

[29] J. Reinik, I. Heinmaa, J. Ritamäki et al., "Direct $\mathrm{CO}_{2}$ sequestration onto alkaline modified oil shale fly ash," Oil Shale, vol. 31, no. 1, pp. 79-90, 2014.

[30] A. Mofarrah, T. Husain, and B. Chen, "Optimizing Cr(VI) adsorption on activated carbon produced from heavy oil fly ash," Journal of Material Cycles and Waste Management, vol. 16, no. 3, pp. 482-490, 2014.

[31] M. J. Khan, A. A. Al-Juhani, R. Shawabkeh, A. Ul-Hamid, and I. A. Hussein, "Chemical modification of waste oil fly ash for improved mechanical and thermal properties of low density polyethylene composites," Journal of Polymer Research, vol. 18, no. 6, pp. 2275-2284, 2011.

[32] R. Shawabkeh, A. Al-Harahsheh, and A. Al-Otoom, "Copper and zinc sorption by treated oil shale ash," Separation and Purification Technology, vol. 40, no. 3, pp. 251-257, 2004.

[33] K. Y. Foo and B. H. Hameed, "Insights into the modeling of adsorption isotherm systems," Chemical Engineering Journal, vol. 156, no. 1, pp. 2-10, 2010.

[34] X. Zhang, X. Zhao, J. Hu, C. Wei, and H. T. Bi, "Adsorption dynamics of trichlorofluoromethane in activated carbon fiber beds," Journal of Hazardous Materials, vol. 186, no. 2-3, pp. 18161822, 2011.

[35] M. S. Chiou and H. Y. Li, "Adsorption behavior of reactive dye in aqueous solution on chemical cross-linked chitosan beads," Chemosphere, vol. 50, no. 8, pp. 1095-1105, 2003.

[36] R. Leyva-Ramos, P. E. Diaz-Flores, J. Leyva-Ramos, and R. A. Femat-Flores, "Kinetic modeling of pentachlorophenol adsorption from aqueous solution on activated carbon fibers," Carbon, vol. 45, no. 11, pp. 2280-2289, 2007.

[37] X. Zhang, S. Chen, and H. T. Bi, "Application of wave propagation theory to adsorption breakthrough studies of toluene on activated carbon fiber beds," Carbon, vol. 48, no. 8, pp. 23172326, 2010.

[38] H. Binici, R. Gemci, A. Kucukonder, and H. H. Solak, "Investigating sound insulation, thermal conductivity and radioactivity of chipboards produced with cotton waste, fly ash and barite," Construction and Building Materials, vol. 30, pp. 826-832, 2012.

[39] Q. Cheng, V. Pavlinek, C. Li, A. Lengalova, Y. He, and P. Saha, "Synthesis and characterization of new mesoporous material with conducting polypyrrole confined in mesoporous silica," Materials Chemistry and Physics, vol. 98, no. 2-3, pp. 504-508, 2006.

[40] F. Zheng, D. N. Tran, B. J. Busche et al., "Ethylenediaminemodified SBA-15 as regenerable $\mathrm{CO}_{2}$ sorbent," Industrial and Engineering Chemistry Research, vol. 44, no. 9, pp. 3099-3105, 2005.

[41] J. Pei and J. S. Zhang, "Determination of adsorption isotherm and diffusion coefficient of toluene on activated carbon at low concentrations," Building and Environment, vol. 48, no. 1, pp. 66-76, 2012.

[42] M. G. Plaza, C. Pevida, A. Arenillas, F. Rubiera, and J. J. Pis, " $\mathrm{CO}_{2}$ capture by adsorption with nitrogen enriched carbons," Fuel, vol. 86, no. 14, pp. 2204-2212, 2007.

[43] S. Choi, J. H. Drese, and C. W. Jones, "Adsorbent materials for carbon dioxide capture from large anthropogenic point sources," ChemSusChem, vol. 2, no. 9, pp. 796-854, 2009.

[44] Z. W. Chen and M. Chanda, "Gel-coated polymeric solid amine for sorption of carbon dioxide from humid air," Journal of Polymer Materials, vol. 19, pp. 381-387, 2002.

[45] V. K. Gupta, I. Ali, Suhas, and D. Mohan, "Equilibrium uptake and sorption dynamics for the removal of a basic dye (basic red) using low-cost adsorbents," Journal of Colloid and Interface Science, vol. 265, no. 2, pp. 257-264, 2003.

[46] M. Monier, "Adsorption of $\mathrm{Hg}^{2+}, \mathrm{Cu}^{2+}$ and $\mathrm{Zn}^{2+}$ ions from aqueous solution using formaldehyde cross-linked modified chitosan-thioglyceraldehyde Schiff's base," International Journal of Biological Macromolecules, vol. 50, no. 3, pp. 773-781, 2012.

[47] I. A. W. Tan, B. H. Hameed, and A. L. Ahmad, "Equilibrium and kinetic studies on basic dye adsorption by oil palm fibre activated carbon," Chemical Engineering Journal, vol. 127, no. 13, pp. 111-119, 2007. 
[48] V. K. Gupta, I. Ali, Suhas, and D. Mohan, "Equilibrium uptake and sorption dynamics for the removal of a basic dye (basic red) using low-cost adsorbents," Journal of Colloid and Interface Science, vol. 265, no. 2, pp. 257-264, 2003.

[49] M. Monier and D. A. Abdel-Latif, "Preparation of crosslinked magnetic chitosan-phenylthiourea resin for adsorption of $\mathrm{Hg}(\mathrm{II}), \mathrm{Cd}(\mathrm{II})$ and $\mathrm{Zn}(\mathrm{II})$ ions from aqueous solutions," Journal of Hazardous Materials, vol. 209-210, pp. 240-249, 2012.

[50] C. Namasivayam and D. Kavitha, "Removal of Congo Red from water by adsorption onto activated carbon prepared from coir pith, an agricultural solid waste," Dyes and Pigments, vol. 54, no. 1, pp. 47-58, 2002.

[51] I. A. W. Tan, A. L. Ahmad, and B. H. Hameed, "Adsorption of basic dye on high-surface-area activated carbon prepared from coconut husk: equilibrium, kinetic and thermodynamic studies," Journal of Hazardous Materials, vol. 154, no. 1-3, pp. 337-346, 2008.

[52] W. Zou, R. Han, Z. Chen, Z. Jinghua, and J. Shi, "Kinetic study of adsorption of $\mathrm{Cu}(\mathrm{II})$ and $\mathrm{Pb}$ (II) from aqueous solutions using manganese oxide coated zeolite in batch mode," Colloids and Surfaces A: Physicochemical and Engineering Aspects, vol. 279, no. 1-3, pp. 238-246, 2006. 

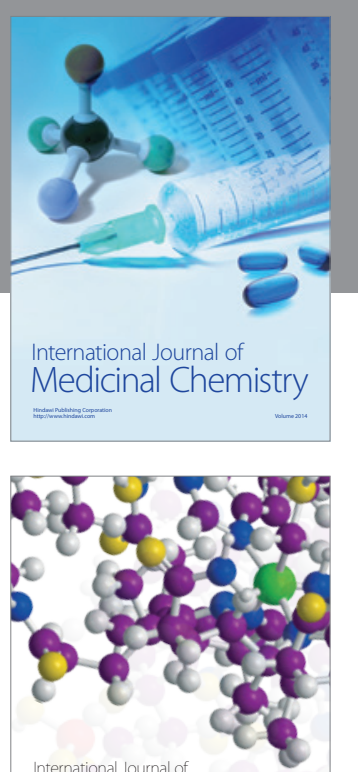

Carbohydrate Chemistry

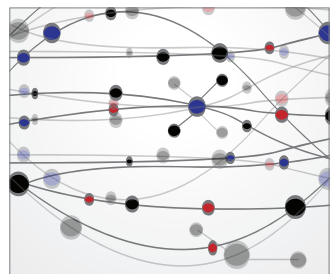

The Scientific World Journal
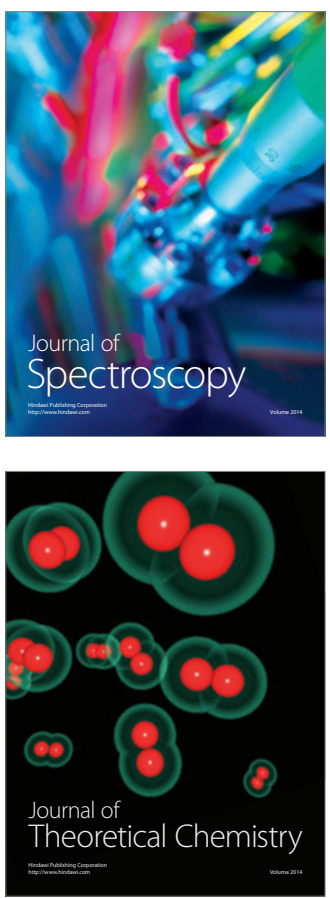
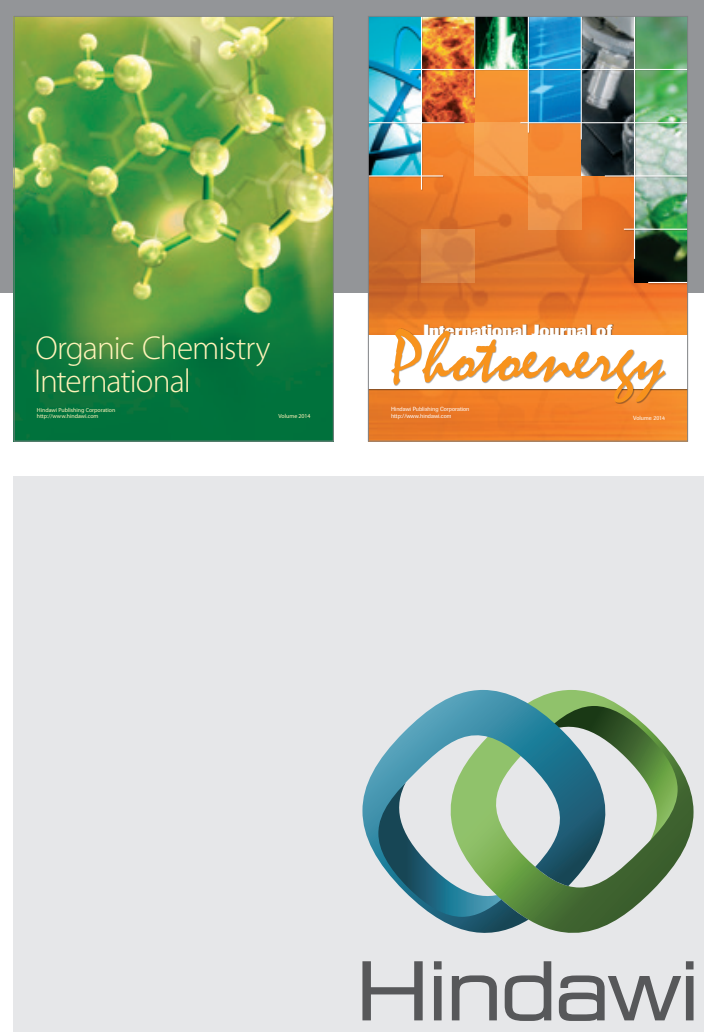

Submit your manuscripts at

http://www.hindawi.com

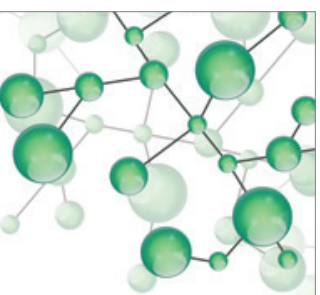

International Journal of

Inorganic Chemistry

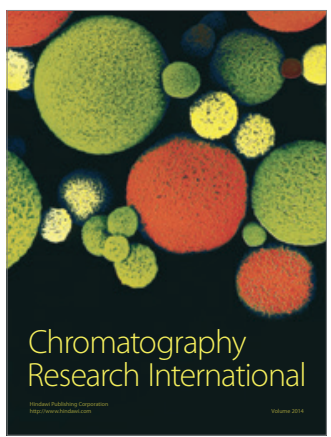

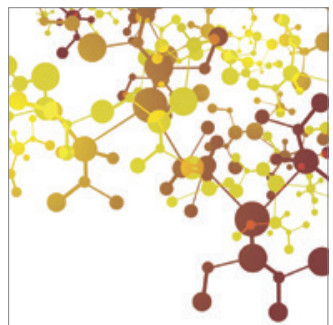

Applied Chemistry
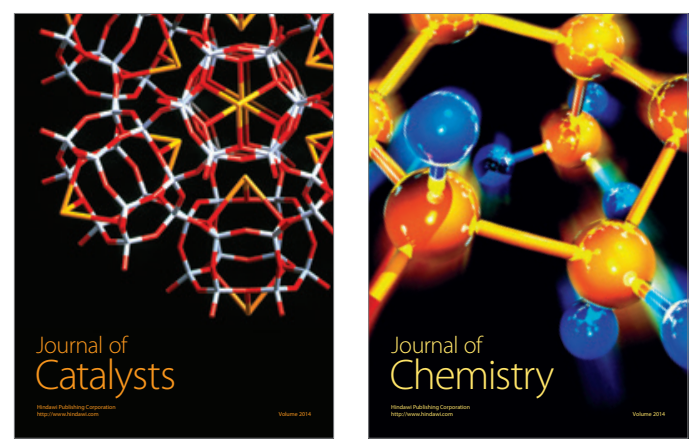
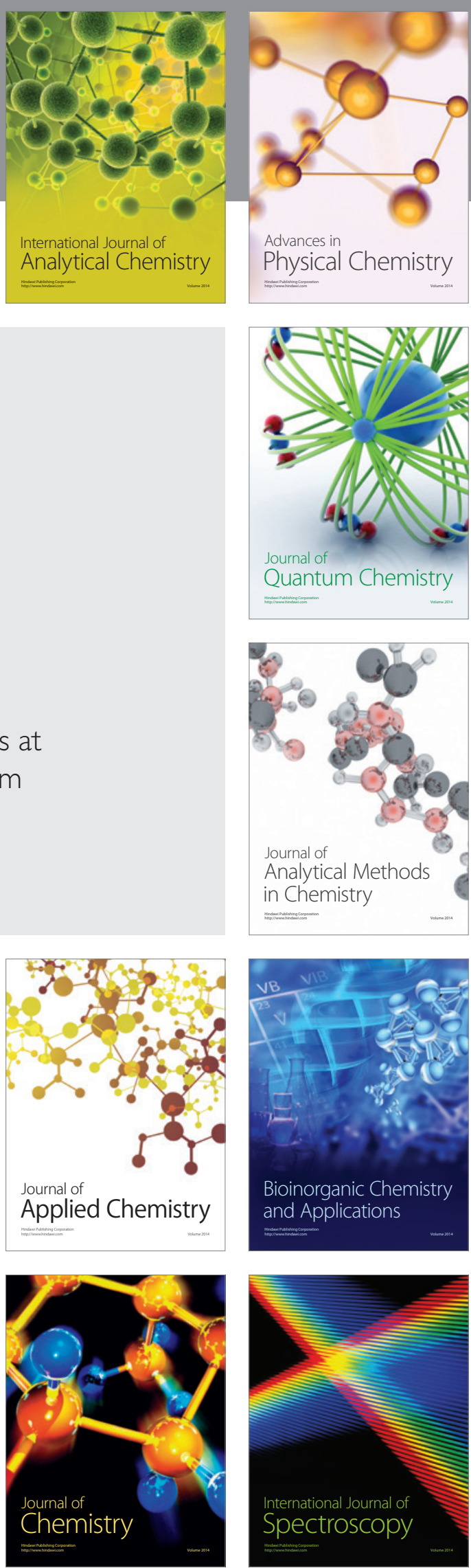